\title{
Cutaneous Wound Healing after Topical Application of Pistacia atlantica Gel Formulation in Rats
}

\section{Pistacia atlantica Jel Formülasyonunun Haricen Uygulamasının Sıçanlarda Oluşturulan Deri Yaraları Üzerindeki liyileştirici Etkisi}

\author{
Seyed Ahmadreza HAMIDI ${ }^{1}$, Aboutorab TABATABAEI NAEINI ${ }^{2}$, Ahmad ORYAN ${ }^{3}$, Mohammad Reza TABANDEH ${ }^{4}$, Nader TANIDEH ${ }^{5}$, Saeed NAZIFI2* $^{*}$ \\ 1Shiraz University, Faculty of Veterinary Medicine, Department of Veterinary Surgery, Shiraz, Iran \\ 2KIMS Collage branch of Rajiv Gandhi University, Student in Dentistry, Bangalouru, India \\ 3 Shiraz University, Faculty of Veterinary Medicine, Department of Pathology, Shiraz, Iran \\ 4 Shiraz University, Faculty of Veterinary Medicine, Department of Biochemistry, Shiraz, Iran \\ 5Shiraz University of Medical Sciences, Department of Stem Cell and Transgenic Research Center, Shiraz, Iran
}

\begin{abstract}
Objectives: This study has been undertaken to investigate the antioxidant activity of the gel formulation from Pistacia atlantica oil extraction on enzymatic antioxidants in experimental wound created in rats.

Materials and Methods: Under anesthesia, a square-shaped skin defect $(2 \times 2 \mathrm{~cm})$ was created aseptically by surgical incision. Then, animals were randomly allocated to four groups (I- untreated controls, II- topically treated with base gel, III- topically treated with $5 \%$ gel, IV- topically treated with $10 \%$ gel).

Results: The results suggest that topical application of Pistacia atlantica oil gels improved reepithelialization with continuous stratum basalis and a mature granulation tissue and adnexa (hair follicles and sweat gland) compared with control and base gel groups. Treatment with $10 \%$ oil gel significantly enhanced the tensile strength, ultimate stress, yield strength and stiffness in this group compared with the control and base gel groups at 21 days post injury. The collagen fibers showed a more organized pattern and the tissue alignment was greater as compared to the control and base gel-treated groups at the same stage.

Conclusion: The results suggest that topical application of Pistacia atlantica oil gel improved the morphological, biochemical and biomechanical properties of experimentally-induced wound defects in rats.
\end{abstract}

Key words: Pistacia atlantica, wound healing, histopathology, biomechanic, skin

öz

Amaç: Bu çalışma, sıçanlarda oluşturulan deneysel yara modelinde Pistacia atlantica yağı ile hazırlanmış jel formülasyonunun, enzimatik antioksidanlar üzerindeki etkisini araştırmak amacıyla yapılmıştır.

Gereç ve Yöntemler: Genel anestezi altına alınan hayvanlarda, aseptik koşullarda, insizyon yapmak suretiyle kare şeklinde yaralar (2x2 cm) olușturulmuștur. Daha sonra, hayvanlar rasgele dört gruba ayrılmıștır (I- tedavi edilmemiș kontrol grubu, II- haricen uygulanan baz jel grubu, IIIharicen \%5 jel uygulanan grup, IV- haricen \%10 jel uygulanan grup).

Bulgular: Sonuçlar, Pistacia atlantica yağı ile hazırlanmış jel formülasyonunun haricen uygulanmasının, kontrol ve baz jel gruplarına kıyasla, bütünlüğü bozulmamıș stratum bazalisi, olgun granülasyon dokusunu, kıl folikülleri ve ter bezleri ile reepitelizasyonu arttırdığını göstermektedir. Yara olușumundan 21 gün sonra, \%10 yağlı jel ile tedavi edilen hayvanların dokularındaki gerilme kuvveti, kopma gerilimi ve bükülme direnci, kontrol ve baz jel grubu ile karşılaştırıldığında önemli ölçüde artmıştır. Aynı evredeki kontrol ve baz jel ile muamele edilen gruplara kıyasla, kollajen liflerin daha organize bir düzenlenme ve dokunun daha düzgün bir iyileşme gösterdiği belirlenmiştir.

Sonuç: Pistacia atlantica yağ jelinin haricen uygulanmasının, sıçanlarda oluşturulan deneysel yaralar üzerinde morfolojik, biyokimyasal ve biyomekanik yönden düzeltici rol oynadığı ortaya koyulmuştur.

Anahtar kelimeler: Pistacia atlantica, yara iyileșmesi, histopatoloji, biomekanik, deri

*Correspondence: E-mail: nazifi@shirazu.ac.ir, Phone: +98-7112286940

Received: 08.10.2015, Accepted: 23.06.2016

-Turk J Pharm Sci, Published by Galenos Publishing House. 


\section{INTRODUCTION}

Plants have immense potential for the management and treatment of wounds. A large number of plants are used by tribal and folklore in many countries for the treatment of wounds. Several plants have been experimentally used as traditional medicines to treat skin disorders and wound injuries.

Pistacia atlantica ( $P$. atlantica) trees grow in large populations in the western, central and eastern parts of Iran. The fruits of $P$. atlantica, which have been used traditionally in treatment of peptic ulcers ${ }^{2}$ are called "Bene" in Iran and have been utilized as food. ${ }^{3}$ Bene hull oil (BHO) comprises of the whole fruit and yields up to $30 \%$ oil. $3,4,5 \mathrm{P}$. atlantica oil contains saturated fatty acids, mono unsaturated fatty acids and the polyunsaturated fatty acids (PUFAs). ${ }^{3}$

The BHO contains tocopherols and tocotrienols as the main constituents in unsaponifiable matter. ${ }^{6}$ The oil displays antioxidant activity which is important for human health. ${ }^{6}$

$\mathrm{BHO}$ contains tocopherols and phenolic constituents, ${ }^{7}$ both of which are very important natural antioxidants by providing an effective protection against oxidative stress., 8

The PUFAs, besides their structural function, they can modulate cell-cell interactions and intracellular signaling. ${ }^{10}$ Linoleic acid is an essential fatty acid (EFA) of 18 carbons, cannot be synthesized by human, which through a desaturation process gives rise to arachidonic acid (20 carbons). Arachidonic acid is a precursor of prostaglandins, leukotrienes, thromboxanes and lipoxins, which in turn act as mediator of platelet function and of inflammatory, vascular, motor and sensory processes, among others. ${ }^{11,12}$ Linoleic acid has also been shown to participate in cell proliferation and inflammatory process, where in the latter it plays a role as a mediator of leukocyte function having chemotactic and stimulatory effects on neutrophils. ${ }^{13}$

Free fatty acids (FFAs) are known to possess anti-Staphylococcus aureus (S. aureus) activity ${ }^{14,15,16}$ and are important components of the innate immune system. ${ }^{17}$ These FFAs, including oleic acid, can function as innate bactericides. ${ }^{18}$ More importantly, it has been found that two FFAs (linoleic acid and dehydrocrepenynic acid) inhibit the bacterial drug resistance by decreasing the transfer frequency of the conjugal DNA. ${ }^{15,19}$

Skin is a biological interface with the environment, and is frequently and directly exposed to prooxidative stimuli, which are known to promote the generation of Reactive Oxygen Species (ROSs) and lipid peroxides. ${ }^{20,21}$ Wounding is another condition that results in a decrease in antioxidants, ${ }^{22,23}$ increase $\mathrm{ROSs}^{24}$ and elevated lipid peroxide levels. ${ }^{25}$ Antioxidants have been shown to promote wound healing $23,24,26,27$ Their levels have been shown to be depleted in the healing cutaneous wounds in normal subjects; however, they partially or completely recovered during the remodelling phase of healing. ${ }^{22}$

Oxygen free radicals play an important role in delaying ischemic wound healing. ${ }^{28}$ Tocopherols have antioxidant properties ${ }^{29}$ and they are active as vitamin E, which makes them particularly important for human health. ${ }^{3}$ Vitamin $E$, the term for a group of tocopherols and tocotrienols, is the major lipid soluble antioxidant in skin that protects the cell membranes from the peroxidative damage. ${ }^{30}$ It has been used to treat almost every type of skin lesion, and is frequently used by the general population to treat burns, surgical scars ${ }^{31}$ and enhances healing of the irradiated skin in rat and increases the healing rate of the patients with chronic post-thrombotic leg ulcers. ${ }^{32,33}$ Vitamin $E$ is an antioxidant that protects the body against the deleterious effects of free radicals. ${ }^{32}$

Antioxidant properties of $P$. atlantica might be an alternative medicine or beneficial herbal drug for the prevention delay wound healing and scar formation during skin healing. Considering the lack of data regarding its efficacy in treating wound healing, the present study was undertaken to fully evaluate the effects of topical application of the gel formulation of this fruit on cutaneous wound healing in an experimentally induced cutaneous wound model in rat.

\section{EXPERIMENTAL}

\section{Animals}

One hundred twenty adult male Sprague Dawley rats weighing 200 to $220 \mathrm{~g}$ were used in the experimets. The animals were housed under standard environmental conditions $\left(23 \pm 1^{\circ} \mathrm{C}\right.$, with $55 \pm 5 \%$ humidity and a $12 \mathrm{~h}$ light/dark cycle) and maintained with free access to water and ad libitum standard laboratory diet (70\% carbohydrates, $25 \%$ proteins, $5 \%$ lipids).

\section{Animal ethics}

The study was approved by the local ethics committee of School of Veterinary Medicine, Shiraz University in accordance with the ethics standards of "Principles of Laboratory Animal Care and was also the recommendations of the European Council Directive (86/609/EEC) of November 24, 1986.

\section{Oil extraction}

The fruit powder was extracted with n-hexane (1:4 wt/vol) by mixing in a dark place at ambient temperature for $48 \mathrm{~h}$. The solvent was evaporated in vacuo to dryness at $40^{\circ} \mathrm{C} .{ }^{34}$

\section{Preparation of the gel}

To prepare $5 \%$ gel, $1 \mathrm{~g}$ carbopol was added to $95 \mathrm{~mL}$ distilled water, and for $10 \%$ gel, $1 \mathrm{~g}$ to $90 \mathrm{~mL}$ distilled water; after 4-5 $h$, all the carbopol powder was dissolved and sodium hydroxide was added to make the gel base. In the next step, $P$. atlantica extracts (5\%, and $10 \%$ ) were added to gel base and used for all experiments.

\section{Wound creation}

The rats were weighed prior to the surgical procedure. The animals were anaesthetised by intramuscular injection of 10 $\mathrm{mg} / \mathrm{kg}$ xylazine hydrochloride $(\mathrm{HCl}$ ) (Xylazine 2\%; Alfasan) as premedication, and $90 \mathrm{mg} / \mathrm{kg}$ ketamine $\mathrm{HCl}$ (Ketamine 10\%; Alfasan) for anaesthesia. Carprofen was subcutaneously injected in all animals $(4 \mathrm{mg} / \mathrm{kg}$ ) just before the operation for preemtive analgesia and then every $24 \mathrm{~h}$ for 3 days postoperatively. A square-shaped $2 \times 2 \mathrm{~cm}$ skin defect was created aseptically by surgical incision at the first thoracic vertebrae and $1 \mathrm{~cm}$ proximal to the first lumbar vertebrae. This method of wound 
induction has been used previously to investigate cutaneous wound healing in rats. ${ }^{35}$

\section{Experimental design}

After wound creation, the animals were assigned into four groups of thirty rats and each group was divided into five subgroups.

Group I, untreated controls,

Group II, topically treated base gel,

Group III, topically treated $5 \%$ gel,

Group IV, topically treated $10 \%$ gel.

The animals of each subgroup $(n=5)$ were sacrificed on the $3^{\text {th }}$, $7^{\text {th }}, 10^{\text {th }}, 14^{\text {th }}$ and $21^{\text {st }}$ day after wound creation and the entire wound with adjoining tissue was cut out.

Digital images of the ulcers were taken, in vivo, in a standardized manner, immediately after the surgical procedure (day zero) and on $3,6,9,12,18$, and 21 postoperative days.

Samples from all these groups were collected for histopathological studies and biochemical analysis. On day 21, samples from all these groups were collected for histopathological studies, biochemical analysis and samples from the five remaining animals in each group were assessed for biomechanical investigation. Similar skin sample from the intact skin of a comparable area far from the site of the initial excision of the same animal was excised as intact control skin.

\section{Sample collection}

The injured area and a rim of the surrounding normal skin, including dermis, epidermis and subcutaneous, were carefully dissected for histopathological and biochemical evaluations. The harvested skin samples were then longitudinally bisected. The first half consisted of normal peripheral tissue and injured area $(5 \times 5 \mathrm{~mm})$ was used for histopathologic and histomorphometric studies and the second half from the center of the lesion, was used for biochemical analysis (approximately $5 \times 5 \mathrm{~mm}$ ). On day 21 , five rats in each group were used for biomechanical sampling. A $1.5 \times 10 \mathrm{~cm}^{2}$ rectangular skin sample with the injured area in the middle was harvested for biomechanical testing.

\section{Histopathological evaluation}

Skin samples from both the wound and comparable contralateral normal skin were fixed in 10\% neutral-buffered formalin, dehydrated in graded ethanol, and cleared in xylol. The specimens were then embedded in paraffin, and sections of $5 \mathrm{~mm}$ in thickness were stained, using hematoxylin and eosin (H\&E) and Masson green trichrome, and studied by a routine light microscope (Olympus, Tokyo, Japan). Histopathological examinations were performed in double-blind fashion. The criteria that were studied in histopathological sections consisted of hemorrhage, fibrin deposition, polymorphonuclear cell and mononuclear cell infiltration, reepithelialization, cornification of epithelium, fibroblast content, collagen content, revascularization, necrosis, presence of fibrocytes, maturation and organization of collagen, fibroblasts and blood vessels. Collagen content was measured on the basis of the connective tissue density measurement in the histopathological sections stained with Masson green trichrome.
The microphotographs were then recorded by a digital camera (Olympus, Tokyo, Japan) and transferred to the computer software (Photoshop CS-5; Adobe) for digital analysis. Five photomicrographs, equivalent to five microscopic fields from each tissue sample, were used for histopathologic and histomorphometric analysis. ${ }^{36,37}$

\section{Biomechanical testing}

The method used has been described previously. ${ }^{37,38,39}$ The skin samples were harvested immediately after euthanasia and placed between sterile sponges soaked with $0.9 \%$ saline, to preserve the normal tissue hydration after harvesting. They were then placed in occlusive bags and stored at $-70^{\circ} \mathrm{C}$ prior to testing. Biomechanical testing was performed 2 days after tissue sampling. Before tensile testing, the samples were thawed at room temperature $\left(15-20^{\circ} \mathrm{C}\right)$. The samples were mounted between two cryoclamps. The cross-sectional area of the samples was calculated by approximating the area as a rectangle, multiplying the thickness and width of the skin samples, which were measured using a digital micrometer (Microtech; Samsung). Biomechanical testing was performed by testing to failure, using a tensile testing machine (Instron Tensile Testing Machine, Instron).

Each sample was loaded by elongating it at a displacement rate of $20 \mathrm{mms}^{-1}$. Load and crosshead displacement data were recorded at $1500 \mathrm{~Hz}$, and a load-deformation curve was generated for each specimen, using Test Works 4 software (SUME Systems Corporation). The ultimate tensile strength, yield strength, stress and stiffness were measured. The stress value $\left(\mathrm{N} \mathrm{mm}^{-2}\right)$ was calculated by dividing the ultimate strength (N) by the cross-sectional area $\left(\mathrm{mm}^{-2}\right)$. Stiffness $\left(\mathrm{Nmm}^{-1}\right)$ was calculated by fitting a linear regression line to the loaddeformation data from $30 \%$ to $90 \%$ of the ultimate tensile strength on the deformation curve.

\section{Determination of the collagen content}

After thawing, the samples' pieces were dried in a hot-air oven at $60-70^{\circ} \mathrm{C}$ until a constant weight was achieved. They were then hydrolysed with $6 \mathrm{~N} \mathrm{HCl}$ for 2 hours at $120^{\circ} \mathrm{C}$. The hydrolysed samples were adjusted to $\mathrm{pH} 7$ and subjected to chloramine-T oxidation. The absorbance of the colored adduct formed with the aldehyde perchloric acid reagent at $60^{\circ} \mathrm{C}$ was recorded at $550 \mathrm{~nm}$, after cooling for $5 \mathrm{~min}$. The data were then multiplied by 7.46 to convert them from hydroxyproline content to collagen content. ${ }^{35,40}$

\section{Glycosaminoglycans content}

Content of Glucosamine (GLA) and galactosamine (GAA), as indices of tissue glycosaminoglycans (GAGs), were analysed according to the methods of Ohkuma et al. ${ }^{41}$ Briefly, $10 \mathrm{mg}$ of the freeze-dried tissue sample was diluted in $2 \mathrm{~mL}$ of $1 \mathrm{~N}$ $\mathrm{HCl}$ and incubated at $120^{\circ} \mathrm{C}$, to produce hydrolysed and dried tissue. Phosphate buffer saline $(0.5 \mathrm{~mL} ; \mathrm{pH} 7)$ and $1 \mathrm{~mL} 4 \mathrm{~N} \mathrm{NaCl}$ were added to the hydrolysed sample. The hydrolysed samples were then converted from acetylated forms of hexoseamines to pyrrole derivatives, using $0.1 \mathrm{~mL}$ of the $6.3 \%$ acetylacetone solution. $0.8 \mathrm{~mL}$ Potassium tetraburate $0.7 \mathrm{M}$ was added and the 
final solution was boiled for 3 min. $10 \mathrm{~g}$ Dimethyl banzaldehyde was blended with $100 \mathrm{~mL}$ acetic acid, containing $12.5 \% 10 \mathrm{~N}$ $\mathrm{HCl}$, and $5 \mathrm{~mL}$ of this solution was added to the boiled sample. The final solution was incubated in a $37^{\circ} \mathrm{C}$ water bath and its absorbance rate was read and analysed at two wavelengths, $550 \mathrm{~nm}$ and $590 \mathrm{~nm}$. The absorbance rate of $590 \mathrm{~nm}$ is related to GLA and that of the $550 \mathrm{~nm}$ belongs to the concentration of GAA in tissue. The concentrations of hydroxyproline, GLA and GAA in each sample were measured using the regression curve from the GLA and GAA standards $(0.0,0.5,1.0,2.0,4.0$ and 8.0 $\mathrm{mg}$ ) and were reported as $\mathrm{gr} / 100 \mathrm{~g}$ of tissue.

\section{Statistical analysis}

After testing to see if the data were normally distributed, quantitative data were compared, using one-way analysis of variance. The post-hoc Tukey test was used to determine differences between the groups. All statistical analyses were performed using SPSS software (v17.0; SPSS Inc.). Differences of $p<0.05$ were considered significant.

\section{RESULTS}

\section{Observations during daily wound care}

The surface area of wounds was calculated and expressed in $\mathrm{cm}^{2}$ as shown in Table 1. There were no significant differences in wound closure between the Bene treated, control and base gel groups. The lesions in the Bene oil gel treated groups showed improved cosmetic results compared with the control and base gel groups (Figure 1).

\section{Histopathological finding}

The data from the histopathological analysis are shown in Table 2. Three days after injury, Bene $5 \%$ and $10 \%$ oil gels resulted in reduction of neutrophils and lymphocyte and increase in fibroblasts but the differences were not significant (Table 2). Seven days after injury, the total fibroblast count was significantly greater in the treated with $5 \%$ Bene oil gel, compared with the control and base gel groups. Treatment with 10\% Bene oil gel increased fibroblast and fibrocytes counts compared with the control and base gel group but these differences were not significant. The neutrophils counts were significantly lower in the lesions treated with Bene compared with the base gel groups (Table 2).

Ten days after injury, treatment with Bene oil gels decreased total lymphocytes compared with the control and base gel groups but this reduction was only significant compared with the control group. Treatment with Bene oil gels also significantly decreased total neutrophils counts compared with the base gel groups ten days after injury (Table 2 ).

Fourteen days after injury, the total lymphocyte and neutrophils counts decreased and the total fibrocytes count was higher in the Bene oil gel treated groups compared with the control and base gel groups but this these differences were not significant (Table 2).

Compared with control and base gel groups, there was a reduction in the total lymphocyte count in both $5 \%$ and $10 \%$ Bene gel groups at twenty-one days after injury but this reduction was only significant in $10 \%$ Bene gel groups. Total fibrocytes count was significantly higher in the $10 \%$ Bene treated group compared with the $5 \%$ Bene, control and base gel groups (Table 2).

There was a significant increase in the number of blood vessels in the lesions treated with $10 \%$ Bene and these differences were significant with the base gel group on day 14 and with the control group on day 21 .

As shown in Table 2, compared to those of the control and base gel treated lesions, fewer lymphocytes and neutrophils were infiltrated in the lesions of the treated animals on day 21 post injury.

Histopathological evaluation of each treatment group was blindly performed by a pathologist according to a modified

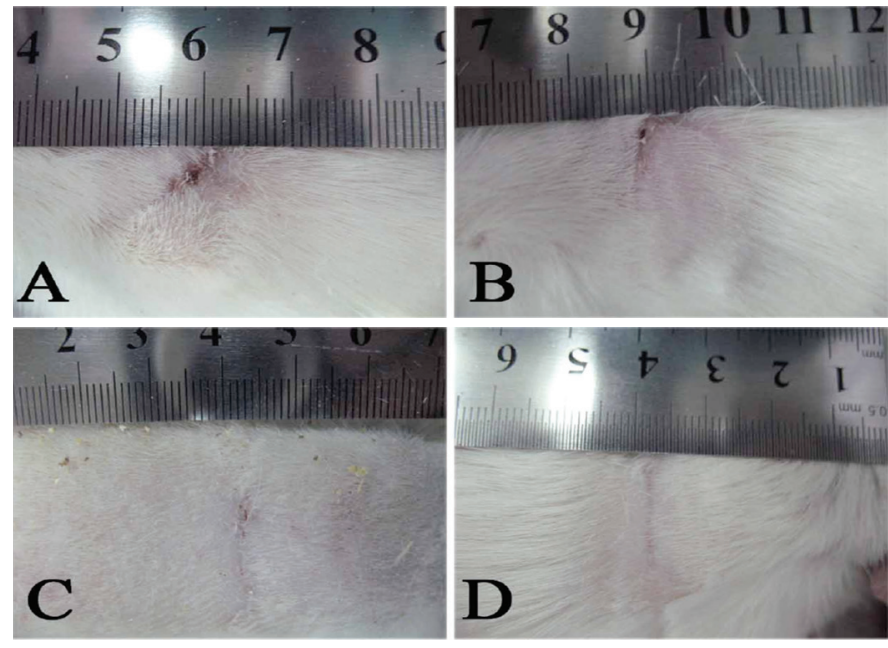

Figure 1. Cosmetic result [control (a), basal gel (b), $5 \%$ Bene oil gel (c) and 10\% Bene oil gel (d)] on day 21 post injury

Table 1. Mean \pm standard error of the mean of wound surface area $\left(\mathrm{cm}^{2}\right)$ in Bene oil gels treated, control and base gel groups on different days

\begin{tabular}{|c|c|c|c|c|c|c|}
\hline Groups & Day 3 & Day 6 & Day 9 & Day 12 & Day 18 & Day 21 \\
\hline Controla & $2.23 \pm 0.11 c$ & $1.5 \pm 0.22$ & $0.79 \pm 0.09$ & $0.34 \pm 0.09$ & $0.15 \pm 0.04$ & $0.13 \pm 0.03$ \\
\hline Base gelb & $2.00 \pm 0.04$ & $1.38 \pm 0.11$ & $0.71 \pm 0.07$ & $0.28 \pm 0.02$ & $0.11 \pm 0.03$ & $0.00 \pm 0.00$ \\
\hline $5 \%$ Benec $^{c}$ & $1.64 \pm 0.20^{a}$ & $1.24 \pm 0.04$ & $0.52 \pm 0.11$ & $0.1 \pm 0.05$ & $0.00 \pm 0.00$ & $0.00 \pm 0.00$ \\
\hline $10 \%$ Bened & $1.81 \pm 0.23$ & $1.33 \pm 0.07$ & $0.52 \pm 0.17$ & $0.21 \pm 0.063$ & $0.00 \pm 0.00$ & $0.00 \pm 0.00$ \\
\hline
\end{tabular}

Characters ( $a=$ control, $b=$ base gel, $c=5 \%$ Bene oil gel, $d=10 \%$ Bene oil gel) represent significant differences for that variable between the associated groups, at that time point 
Table 2. Mean \pm standard error of the mean of Histopathologic and histomorphometric analysis of Bene oil gels compare with control and base gel treated group on different days post injury

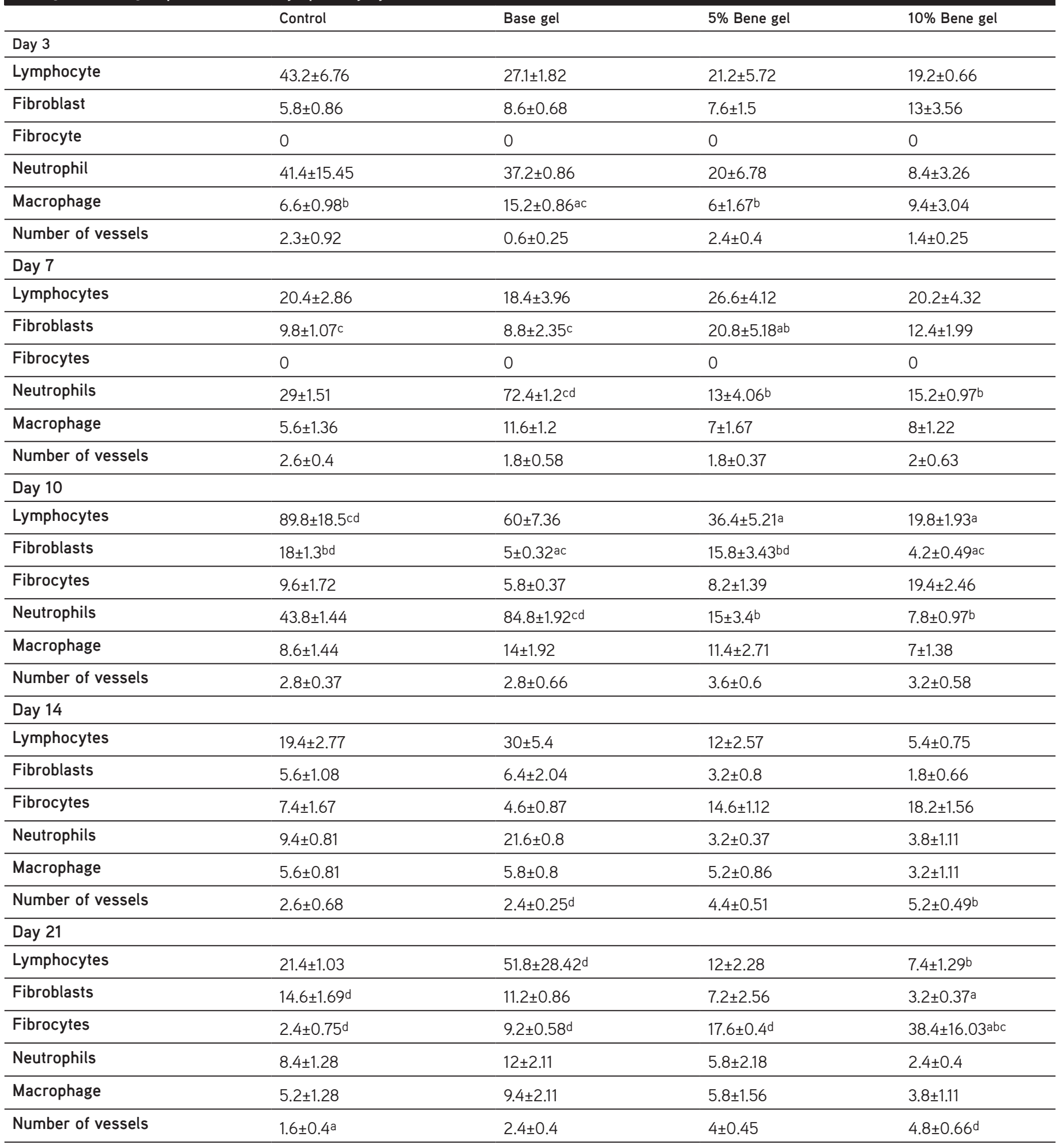

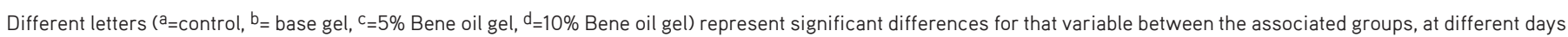

scoring system for surgical wound healing (Table 3). ${ }^{42}$ This scoring system was used to determine grade of healing in the lesion of each treatment group. This scoring system was based on the following repair indices: epithelialization, collagen deposition, inflammation, ulceration, and necrosis.
As has been shown in Figure 2, the mean score of the $5 \%$ and $10 \%$ Bene treated groups were respectively higher than those of the control and base gel groups. Tissue regeneration in the $5 \%$ and $10 \%$ Bene treated wounds got a better score than the control and base gel groups but the differences were not 
significant. Figure 3 shows representative photomicrograph of skin sections stained with hematoxylin and eosin and Masson green trichrome which have been properly repaired in the treated group. On day 14 , the $5 \%$ and $10 \%$ Bene treated groups revealed more developed reepithelialization and continuous stratum basalis with a mature granulation tissue, while the lesions in the control group showed necrosis, and immature granulation tissue (Figure 3m, 3n, 3o, 3p).

On day 21 , the $5 \%$ and $10 \%$ Bene treated groups revealed full collagen deposition and full reepithelialization with a mature granulation tissue and properly developed adnexa (hair follicles and sweat gland) compared with control and base gel groups (Figure 3q, 3r, 3s, 3t). The collagen fibers showed a more organized pattern and the tissue alignment was greater as compared to the control and base gel treated groups at the same stage (Figure 3u, 3v, 3w, 3x).

There was no evidence of pus accumulation, fibrin deposition or edema in the lesions of treated animals during the 21 day treatment period with Bene oil gels.

\section{Biomechanical findings}

The biomechanical findings are presented in Table 4. Treatment with $10 \%$ Bene oil gel significantly increased the tensile strength, maximum stress, yield strength and stiffness of this group compared with the control and base gel groups after 21 days post injury ( $p<0.001$ ). Treatment with $5 \%$ Bene oil gel increased the tensile strength, ultimate stress, yield strength and stiffness of this group compared with the control and base gel group but the differences were not significant at this period. The lesions of all groups showed significantly lower tensile strength, ultimate stress, yield strength and stiffness than the intact skin at this stage.

\section{Biochemical findings}

The biochemical findings are presented in Figure 4. There was no significant difference in the GLA content of the injured samples on day 21 after injury with the Bene oil treated gels and the control and base gel groups. $10 \%$ Bene oil gel significantly increased the galactoseamin content of the injured samples three days after treatment compared with the $5 \%$ Bene $(p=0.036)$, control $(p=0.048)$ and base gel $(p=0.039)$ groups during the period of this experiment.

Treatment with 10\% Bene oil gel significantly increased the Hydroxyproline content of the injured samples on day 10 post injury ( $p=0.007$ ) compared with the control group, and the base gel on day 14 post injury ( $p=0.032)$.

Seven days after injury, treatment with $10 \%$ Bene oil gel significantly increased the collagen content of the injured samples compared with the control group $(p=0.013)$.

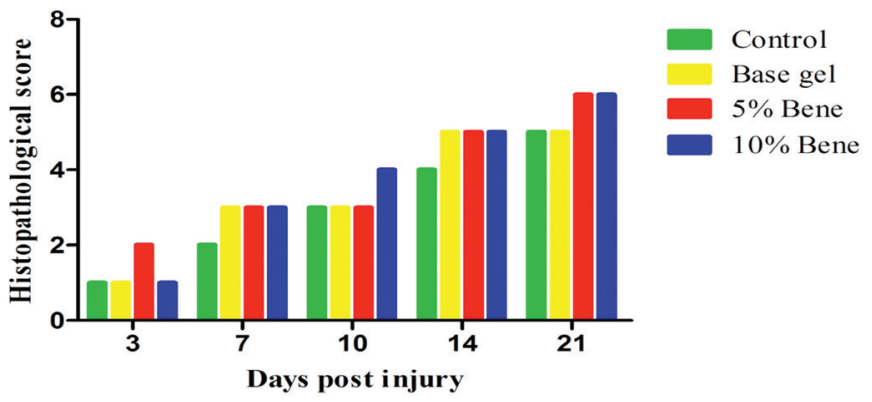

Figure 2. The mean score of the $5 \%$ and $10 \%$ Bene oil gel treated groups compared with the control and base gel treated groups

Table 3. Histopathological scoring of the cutaneous wound healing, This scoring system was used to determine grade of healing in the lesion of each treatment group

\begin{tabular}{|c|c|c|c|c|c|c|c|}
\hline Score & Epithelialization & Collagen deposition & Inflammation & Neovascularization & Necrosis & Granulation tissue & Adenexa (hair follicle) \\
\hline 1 & None & None & Moderate & None & Focal & Immature & Distraction \\
\hline 2 & None & Partial & Mild & $<3$ & None & Immature & Distraction \\
\hline 3 & None & Partial & Mild & $<3$ & None & Mild mature & Distraction \\
\hline 4 & Partial & Partial & Mild & $<5$ & None & Mod mature & Distraction \\
\hline 5 & Complete, mature & Complete, regular & None & $>5$ & None & Fully mature & Distraction \\
\hline 6 & Complete, mature & Complete, regular & None & $>5$ & None & Fully mature & Repair \\
\hline
\end{tabular}

Table 4. Mean \pm standard error of the mean of biomechanical performance of Bene oil gels compare with control and base gel on different days post injury

\begin{tabular}{|c|c|c|c|c|c|}
\hline & Control & Base gel & $5 \%$ Bene & $10 \%$ Bene & Intact skin \\
\hline Maximum stress $\left(\mathrm{kg} / \mathrm{mm}^{2}\right)$ & $0.78 \pm 0.05$ de & $0.72 \pm 0.09 \mathrm{de}$ & $1.21 \pm 0.2^{\mathrm{e}}$ & $1.87 \pm 0.18$ abe & $4.72 \pm 0.21 \mathrm{abcd}$ \\
\hline Tensile strength (kg) & $15.64 \pm 0.88 \mathrm{de}$ & $14.48 \pm 1.73$ de & $26.28 \pm 3.99 e$ & $37.48 \pm 2.6$ abe & $94.4 \pm 4.3 \mathrm{abcd}$ \\
\hline Yield strength (kg) & $10.43 \pm 0.58$ de & $9.65 \pm 1.16$ de & $17.52 \pm 2.66 \mathrm{e}$ & $24.99 \pm 2.4$ abe & $62.93 \pm 2.87 \mathrm{abcd}$ \\
\hline Stiffness (kg/mm) & $9.29 \pm 0.48$ de & $8.69 \pm 1.04 \mathrm{de}$ & $15.77 \pm 2.4 \mathrm{e}$ & $22.49 \pm 2.16 \mathrm{abe}$ & $56.6 \pm 2.61^{\mathrm{abcd}}$ \\
\hline
\end{tabular}

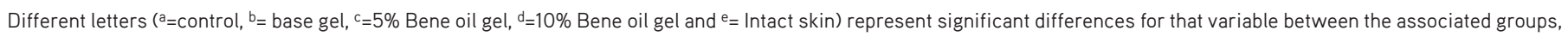
at different days 


\section{DISCUSSION}

These results suggest that topical application of Bene oil gels (especially $10 \%$ Bene) resulted in improved reepithelialization

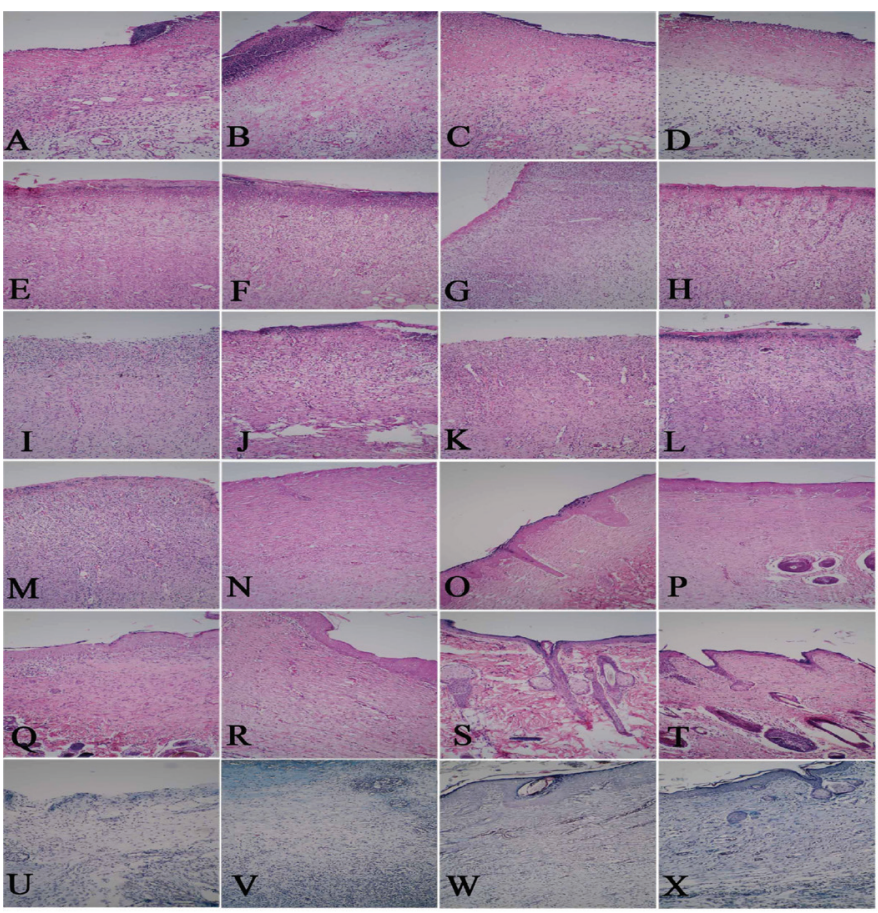

Figure 3. Tissue sections of the control (a, e, l, m, q), basal gel (b, f, j, n, r), $5 \%$ Bene oil gel (c, g, k, o, s) and 10\% Bene oil gel groups (d, h, l, p, t), on days 3 , $7,10,14$ and 21 post injury and Masson green thricrome of this groups on day 21 post injury ( $u, v, w, x)$
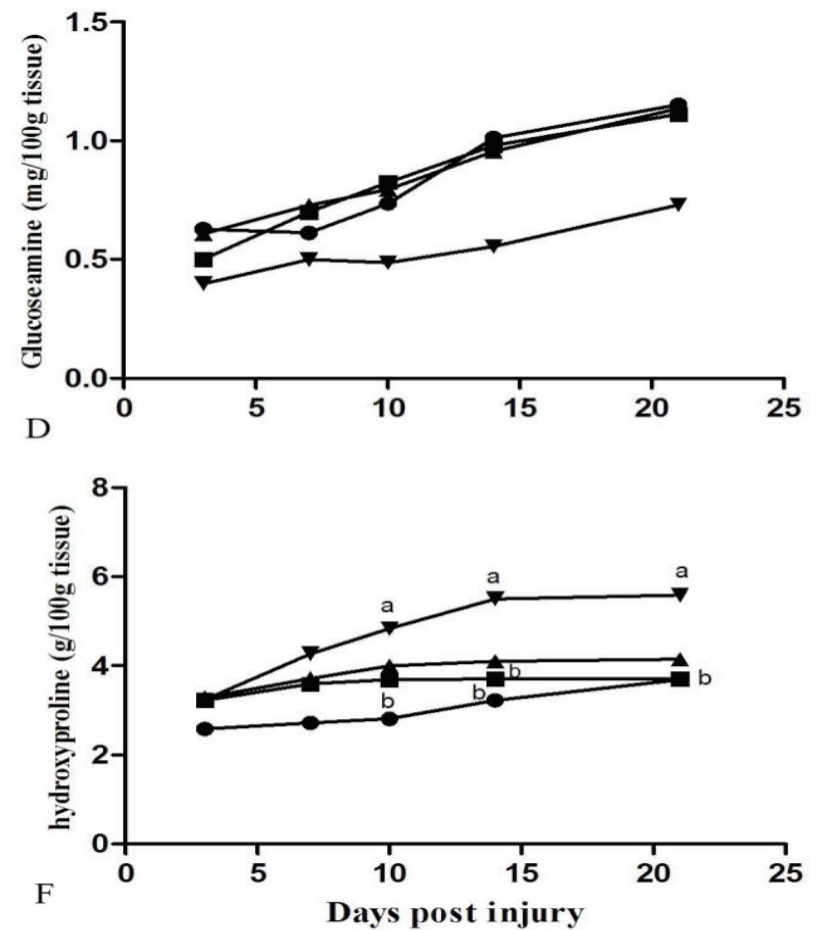

with continuous stratum basalis and a mature granulation tissue and adnexa (hair follicles and sweat gland) compared with control and base gel groups. Treatment with 10\% Bene oil gel significantly enhanced the tensile strength, ultimate stress, yield strength and stiffness of this group compared with the control and base gel group at 21 days post injury. The collagen fibers showed a more organized pattern and the tissue alignment was greater as compared to the control and base gel treated groups at the same stage.

However, to our knowledge, this is the first time that this reagent has been used on experimentally induced cutaneous wound defects in rats and except for the antioxidants potential of this reagent, its other beneficial effects, such as production of collagen and increased stiffness, its influence on mesenchymal cells and tissue maturity, are novel and suggest this reagent as a potent initiator of wound healing.

Consist with our finding Tanideh et al. ${ }^{43}$ showed that a high dose of $P$. atlantica fruit oil extract, administered orally and rectally can improve colitis physiologically and pathologically in a rat model, and may be efficient for ulcerative colitis.

The balance between free radicals and antioxidants may be disrupted in many diseases. ${ }^{44}$ Wounding is condition that results in reduction of the antioxidants. ${ }^{22,23}$ Hamidi et al. ${ }^{23}$ showed that excision of the wound leads to oxidative stress and decrease significantly level of superoxide dismutase, plasma glutathione peroxidase and catalase, and also increase level of malondialdehyde during wound closure in control groups and topical administration of $P$. atlantica gels causes remarkable changes in antioxidant parameter during wound closure
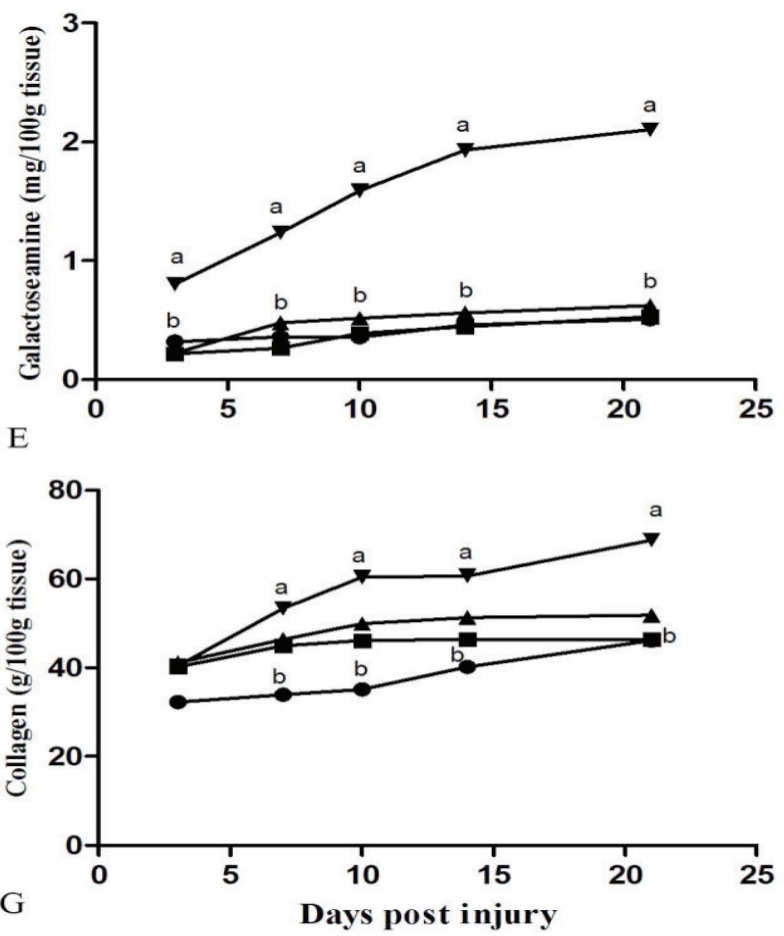

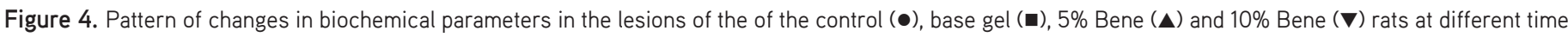

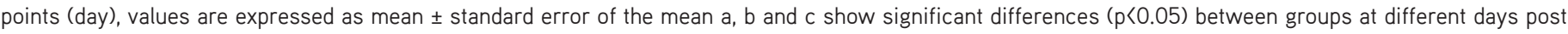
injury are indicated 
(especially gel 10\%) via pro-oxidative and antioxidant activity which can improve oxidative stress.

Guo and DiPietro ${ }^{45}$ suggested that vitamin E, an anti-oxidant, maintains and stabilizes cellular membrane integrity by providing protection against destruction by oxidation. We showed Bene oil gel has anti-inflammatory properties and has been suggested to have a role in decreasing excess scar formation in wounds. Consistent with our finding, Burgess ${ }^{46}$ and Arnold and Barbul ${ }^{47}$ showed that vitamin $\mathrm{E}$ also has antiinflammatory properties and has been suggested to have a role in decreasing excess scar formation in chronic wounds.

Another study showed in acute rodent wounds, the levels of vitamin $\mathrm{E}$, ascorbate and glutathione decreased by $60-70 \%$ as compared to normal skin and only the levels of glutathione recovered completely within 14 days after wounding. ${ }^{22}$ In another study it has been shown that strong reduction levels of glutathione, Vitamin E and ascorbate were observed in wounded skin of immunosuppressed rats as compared to the immunocompetent animals. ${ }^{48}$ In addition, it has been found that palm vitamin $E$ extract, which contains a mixture of $60 \%$ tocotrienol and $40 \%$ tocopherol, enhances wound healing in diabetic rats and increases the activity of the GPx enzyme. ${ }^{49}$ Consistent with our finding Arnold and Barbul ${ }^{47}$ and Burgess ${ }^{46}$ indicated that vitamin $\mathrm{E}$ supplementation is beneficial to wound healing, ${ }^{50}$ and topical vitamin $\mathrm{E}$ has been widely promoted as an anti-scarring agent and Zampieri et al. ${ }^{51}$ also showed that topical application of vitamin E could improve the cosmetic results of surgical incisions. Topical formulations of vitamin $\mathrm{E}$ have been promoted to help wound healing, presumably because they inhibit collagen synthesis and reduce both fibroblast proliferation and inflammation. ${ }^{31,52}$

Erhan et al. ${ }^{53}$ suggest that both vitamin $E$ and selenium promote wound healing activity by increasing the blood flow in the wound region. New evidences from the studies on diabetic mouse models point to an involvement of oxidative stress in diabetic wound healing and significantly improved wound healing by topical vitamin E. ${ }^{54,55}$ Another finding showed vitamin $\mathrm{E}$ or $\alpha$-tocopherol supplementation reduced the levels of lipid peroxides in the wound tissue of diabetic rats, and the wound healing process was enhanced, in particular in the Vitamin E treated animals. ${ }^{56}$ Tsoureli-Nikita et al. ${ }^{57}$ performed a clinical single, blind, placebo controlled study in which 96 atopic dermatitis patients were treated with either placebo or oral vitamin $\mathrm{E}$ (400 IE/day) for 8 months.

Fatty acids have important roles in immune and inflammatory responses. They are important components of the cell membrane. ${ }^{58,59}$ In this experiment no evidence of pus accumulation at Bene treated group was seen. Chen et al. ${ }^{18}$ showed that oleic acid (C18:1) exerts excellent antimicrobial activity against various $S$. aureus strains, including a hospitalacquired methicillin-resistant $S$. aureus strain (MRSA252) and a community associated-MRSA strain (USA300). It was also shown that oleic acid may have broad-spectrum antimicrobial activity against $S$. aureus bacteria and can suppress growth of gram-positive bacteria including Staphylococcus epidermidis, Listeria monocytogenes and Bacillus anthracis.
EFA, such as linoleic acid, have been employed for the prevention ${ }^{60}$ and treatment of pressure ulcers. ${ }^{61}$ The deficiency of EFA has impaired cutaneous wound healing in mice, rats ${ }^{62,63}$ and infants. ${ }^{64}$ Fatty acids have been shown to control the functions of neutrophils. These cells play a key role in the healing process by releasing various cytokines at first stage of healing. Therefore, the effect of fatty acids on neutrophils may play an important role in the healing process, in particular, on the control of angiogenesis and cell proliferation. Simpson and Ross $^{65}$ indicated that neutrophils are not essential for proper wound healing in the skin during wound healing. Studies using antibody-based methods to reduce neutrophils in mice suggest that neutrophils can deter healing, as depletion of neutrophils led to significantly faster reepithelialization rates compared to the control wounds. ${ }^{66,67}$ We showed that treatment with Bene resulted in remarkable reduction in the number of neutrophils during the period of healing.

Pereira et al. ${ }^{68}$ showed that oleic and linoleic acids cause marked changes in the wound during the inflammation period of the healing process. These fatty acids showed a proinflammatory effect on cutaneous wound healing. Cardosoa et al. ${ }^{69}$ showed that linoleic and oleic acids can modulate the closure of surgically induced skin wounds.

Linoleic acid can be used for the biosynthesis of arachidonic and Prostaglandins in the epidermis. ${ }^{68}$ Arachidonic acid and its metabolites are mediators of several events during wound healing, such as cell growth, angiogenesis and synthesis of extracellular matrix. Prostaglandins are involved in tissue repair, cell spreading and migration and epidermal cell proliferation. ${ }^{70}$

The nutritional deficiency of EFA has also been associated with deficient cutaneous wound healing as reported in mice, rats ${ }^{62,63}$ and infants. ${ }^{64}$ Fatty acid mixtures containing oleic and linoleic acids have been used for prevention and treatment of pressure ulcers. ${ }^{60,71}$ Topical application of fatty acids also improves hydration, elasticity and prevents skin breakdown in patients under poor nutritional conditions. ${ }^{10,61,62}$

Although the role of vitamin $E$ in the treatment and prevention of skin disorders seems to be effective ${ }^{72,73}$ there are controversial data about the use of topical vitamin $E$ to prevent and treat hypertrophic scars. Some authors have shown that topical applications of vitamin E do not have significant effects in the enhancement of the cosmetic results of surgical incisions. It seems that current evidence from the literature does not support the conclusion that the topical use of vitamin E cream can reduce scar formation. In fact, studies report some adverse effects related to its use..$^{74}$ Some reports indicate that vitamin $E$ may impair collagen synthesis and wound healing in animals ${ }^{52,75}$ whereas other authors report enhanced healing in irradiated rat skin and patients with post thrombotic leg ulcers. ${ }^{76}$

\section{CONCLUSION}

The results suggest that, there was a reduction in the total lymphocyte count in both $5 \%$ and $10 \%$ Bene gel groups at twenty one days compared with control and base gel groups after injury but this reduction was only significant in $10 \%$ Bene gel groups. Total fibrocyte count was significantly higher 
in the $10 \%$ Bene treated group compared with the $5 \%$ Bene, control and base gel groups. topical application of Bene oil gels (especially Bene 10\%) resulted in improved reepithelialization with continuous stratum basalis and a mature granulation tissue and adnexa (hair follicles and sweat gland) compared with control and base gel groups. The lesions in the Bene oil gel treated groups showed improved cosmetic results compared with the control and base gel groups during wound repair. Treatment with $10 \%$ Bene oil gel significantly enhanced the tensile strength, ultimate stress, yield strength and stiffness of this group compared with the control and base gel group at 21 days post injury. The collagen fibers showed a more organized pattern and the tissue alignment was greater as compared to the control and base gel treated groups at the same stage.

\section{ACKNOWLEDGEMENTS}

The authors would like to thank the Research Council of Shiraz University and School of Veterinary Medicine, Shiraz University for financial and technical support of this study (Grant No. 71-GR-VT-5).

Conflict of Interest: No conflict of interest was declared by the authors.

\section{REFERENCES}

1. Lingaraju GM, Krishna V, Joy Hoskeri H, Pradeepa K, Venkatesh, Babu PS. Wound healing promoting activity of stem bark extract of Semecarpus anacardium using rats. Nat Prod Res. 2012;26:2344-2347.

2. Abdel-Rahman HY, Youssef AM. Mastich as an antioxidant. J Am Oil Chem Soc. 1975;52:423-423.

3. Farhoosh R, Khodaparast MHH, Sharif A. Bene hull oil as a highly stable and antioxidative vegetable oil. Eur J Lipid Sci Tech. 2009;111:1259-1265.

4. Daneshrad A, Aynehchi Y. Chemical studies of the oil from pistacia nuts growing wild in Iran. J Am Oil Chem Soc. 1980;57:248-249.

5. Farhoosh R, Tavakoli J, Khodaparast M. Chemical Composition and Oxidative Stability of Kernel Oils from Two Current Subspecies of Pistacia atlantica in Iran. J Am Oil Chem Soc. 2008;85:723-729.

6. Farhoosh R, Hossein M, Tavassoli-Kafrani, Sharif A. Antioxidant activity of the fractions separated from the unsaponifiable matter of bene hull oil. Food Chem. 2011;126:583-589.

7. Sharayei $P$, Farhoosh R, Poorazrang H, Khodaparast M. Effect of bene kernel oil on the frying stability of canola oil. J Am Oil Chem Soc. 2010;88:647-654.

8. Lampi A M, Kajata L, Kamal-Eldin A, Piironen V. Antioxidant activities of a- and g-tocopherols in the oxidation of rapeseed oil triacrylglycerols. J Am Oil Chem Soc. 1999;76:749-755.

9. Papas A M. Antioxidant status, diet, nutrition and health, CRC Press. Boca Raton FL (USA). 1998.

10. Cardoso CR, Souza MA, Ferro EA, Favoreto S Jr, Pena JD. Influence of topical administration of $n-3$ and n-6 essential and n-9 nonessential fatty acids on the healing of cutaneous wounds. Wound Repair Regen. 2004;12:235-243.

11. Hatanaka E, Curi R. Fatty acids and wound healing: a review. Rev Bras. Farm 2007;88:53-58.

12. Ortonne J, Clevy J. Physiology of cutaneous cicatrization. Rev Prat. 1994:44:1733-1737.
13. Moch $D$, Sheva $T$, Heihn $H$, Schimidt $D$, Buntroc $P$. The linoleic acid metabolite 2 Ds-hidroxi-10, 12 (E-Z): octadecadienoic acid is a strong, proinflammatory mediator in a experimental would healing model of the rat. Biochim Biophys Acta. 1990;49:201-207.

14. Clarke SR, Mohamed R, Bian L, Routh AF, Kun JFK, Mond JJ, Tarkowski A, Foster SJ. The Staphylococcus aureus surface protein IsdA mediates resistance to innate defenses of human skin. Cell Host Microbe. 2007;1:199-212.

15. Smith PA, Romesberg FE. Combating bacteria and drug resistance by inhibiting mechanisms of persistence and adaptation. Nat Chem Biol. 2007:3:549-556.

16. Sado Kamdem S, Guerzoni M E, Baranyi J, Pin C. Effect of capric, lauric and alpha-linolenic acids on the division time distributions of single cells of Staphylococcus aureus. Int J Food Microbiol. 2008;128:122-128.

17. de Pablo MA, Cienfuegos GAD. Modulatory effects of dietary lipids on immune system functions. Immunol Cell Biol. 2000;78:31-39.

18. Chen $\mathrm{CH}$, Wang Y, Nakatsuji T. An innate bactericidal oleic acid effective against skin infection of methicillin-resistant Staphylococcus aureus: A therapy concordant with evolutionary medicine. J Microb Biot. 2011;21:391-399.

19. Fernandez-Lopez R, Machon C, Longshaw CM. Unsaturated fatty acids are inhibitors of bacterial conjugation. Microbiology 2005;151:3517-3526.

20. Guo $Q$, Packer L. Ascorbate dependent recycling of vitamin $E$ homologue trolox by dihydrolipoate and glutathione in murine skin homogenate. Free Radic Biol Med. 2000;29:368-374.

21. Picardo M, Passi S. Skin Immune System. CRC Press, New York, PP, 1997;207-226.

22. Shukla A, Rasik A, Patnaik G. Depletion of reduced glutathione, ascorbic acid, vitamin $E$ and antioxidant defence enzymes in a healing cutaneous wound. Free Radical Res Com. 1997;269:93-101.

23. Hamidi S A, Tabatabaii Naeini A, Tanideh N, Nazifi S. Effects of Pistacia atlantica (subsp. Mutica) oil extract on antioxidant activities during experimentally induced cutaneous wound healing in rats. Veterinary Sci. Dev 2015;5:5672.

24. Martin A. The use of antioxidants in healing. Dermatol Surg. 1996;22:156-160.

25. Niwa Y, Kanoh T, Sakane T, Soh H, Kawai S, Miyachi Y. The ratio of lipid peroxides to superoxide dismutase activity in the skin lesions of patients with severe skin disease: An accurate prognostic indicator. Life Sci. 1987;40:921-927.

26. Silaeva S, Guliaeva N, Khatsernova B, Onufriev M, Nikolaev A. Effects of 4-methyluracil and carnosine on healing of skin wounds in rats. Bull Exp Biol Med. 1990;109:180-182.

27. Slater T. Free radical mechanisms in tissue injury. Biochem J. 1984;222:1-5.

28. Senel O, Cetinkale O, Ozbay G, Ahcioglu F, Bulan R. Oxygen free radicals impair wound healing in ischemic rat skin. Ann Plast Surg. 1997;39:516-523.

29. Schafer M, Werner S. Oxidative stress in normal and impaired wound repair. Pharmacol Res. 2008;58:165-171.

30. Suleyman H, Gumustekin K, Taysi S, Keles S, Oztasan N, Aktas O. Beneficial effects of Hippophae rhamnoides $L$. on nicotine induced oxidative stress in rat blood compared with vitamin E. Biol Pharm Bull. 2002;25:1133-1136.

31. Baumann LS, Spencer J. The effects of topical vitamin E on the cosmetic appearance of scars. Dermatol Surg. 1999;25:311-315.

32. Rojas Al, Phillips TJ. Patients with chronic leg ulcers show diminished levels of vitamins $A$ and $E$, carotenes, and zinc. Dermatol Surg. 1999;25:601-604.

33. Varoglu E, Seven B, Gumustekin K, Aktas O, Sahin A, Dane S. The effects of vitamin $E$ and selenium on blood flow to experimental skin burns in rats using the $133 \mathrm{Xe}$ clearance technique Cent. Eur J Med Chem. 2010;5:219-223. 
34. Farhoosh R, Tavassoli-Kafrani MH. Frying performance of the hull oil unsaponifiable matter of Pistacia atlantica subsp, Mutica. Eur J Lipid Sci Tech. 2010;112:343-348.

35. Oryan A, Tabatabaei Naeini A, Moshiri A, Mohammadalipour A, Tabandeh MR. Modulation of cutaneous wound healing by silymarin in rats. $J$ Wound Care. 2012;21:457-464.

36. Oryan A, Khalafinezad A, Toloo N, Soltani Rad MN. Effects of 4-chloro2,6-bis (2-hydroxylbenzyl) phenol on healing of skin wounds and growth of bacteria. J Vet Med. 2007;54:585-591.

37. Oryan A, Moshiri A, Meimandiparizi AH. Effects of sodium-hyaluronate and glucosamine-chondroitin sulfate on remodeling stage of tenotomized superficial digital flexor tendon in rabbits: a clinical, histopathological, ultrastructural, and biomechanical study. Connect Tissue Res. 2011;52:329-339.

38. Oryan A, Moshiri A. A long term study on the role of exogenous human recombinant basic fibroblast growth factor on the superficial digital flexor tendon healing in rabbits. J Musculoskelet Neuronal Interact. 2011;11:185-195.

39. Trudel G, Doherty GP, Koike Y. Restoration of strength despite low stress and abnormal imaging after Achilles injury. Med Sci Sports Exerc. 2009; 41:2009-2016.

40. Edwards CA, O'Brien WDJ. Modified assay for determination of hydroxyproline in a tissue hydrolyzate. Clinica Chimica Acta. 1980;104:161-167.

41. Ohkuma S, Shinohara T, Furuhata T. Determination of hexosamines by modified Morgan-Elson reaction. Proc Jpn Acad. 1996;42:970-974.

42. Abramov Y, Golden B, Sullivan M. Histologic characterization of vaginal vs. abdominal surgical wound healing in a rabbit model. Wound Repair Regen. 2007;15:80-86.

43. Tanideh N, Masoumi S, Hosseinzadeh M, Safarpour A R, Erjaee H, KoohiHosseinabadi O, Rahimikazerooni S. Healing effect of Pistacia atlantica fruit oil extract in acetic acid-induced colitis in rats. Iran J Med Sci. 2014;39:522-528.

44. Abd Ellah M. Involvement of free radicals in animal diseases. Comparative Clinical Pathology. 2010;19:615-619.

45. Guo S, DiPietro LA. Factors Affecting Wound Healing. J Dent Res. 2010;89:219-229.

46. Burgess C. Topical vitamins. J Drugs Dermatol. 2008;7:2-6.

47. Arnold M, Barbul A. Nutrition and wound healing. Plast Reconstr Surg. 2006;117:42-58.

48. Gupta A, Singh R, Raghubir R. Antioxidant status during cutaneous wound healing in immunocompromised rats. Mol Cell Biochem. 2002;241:1-7.

49. Musalmah M, Fairuz A, Gapor M, Wan Ngah W. Effect of palm vitee on wound healing in normal and diabetic rats. Biochem Mol Biol J. 2001;6:34-39.

50. Heyman H, Van De Looverbosch D, Meijer E, Schols J. Benefits of an oral nutritional supplement on pressure ulcer healing in long-term care residents. J Wound Care. 2008;17:476-480.

51. Zampieri N, Zuin V, Burro R, Ottolenghi A, Saverio Camoglio F. A prospective study in children: Pre- and post-surgery use of vitamin $E$ in surgical incisions. J Plast Reconstr Aesthet Surg. 2010;63:1474-1478.

52. Ehrlich H, Tarver H, Hunt T. Inhibitory effects of vitamin $E$ on collagen synthesis and wound repair. Ann Surg. 1972;175:235-240.

53. Erhan V, Bedri S, Kenan G, Omer A, Ali S, Senol D. The effects of vitamin $E$ and selenium on blood flow to experimental skin burns in rats using the 133Xe clearance technique. Cent Eur J Med. 2010;5:219-223.

54. Altavilla D, Saitta A, Cucinotta D. Inhibition of lipid peroxidation restores impaired vascular endothelial growth factor expression and stimulates wound healing and angiogenesis in the genetically diabetic mouse. Diabetes. 2001;50:667-674.

55. Galeano M, Torre V, Deodato B. Raxofelast, a hydrophilic vitamin E-like antioxidant, stimulates wound healing in genetically diabetic mice. Surgery. 2001;129:467-477.
56. Musalmah M, Nizrana M, Fairuz A, NoorAini A, Azian A, Gapor M. Comparative effects of palm vitamin e and alpha-tocopherol on healing and wound tissue antioxidant enzyme levels in diabetic rats. Lipids 2005; $40: 575-580$.

57. Tsoureli-Nikita E, Hercogova J, Lotti T, Menchini G. Evaluation of dietary intake of vitamin $E$ in the treatment of atopic dermatitis: a study of the clinical course and evaluation of the immunoglobulin E serum levels. J Dermatol. 2002;41:146-150.

58. Cabral G. Lipids as bioeffectors in the immune system. Life Sci. 2005;77:1699-1710.

59. Peres C, Otton R, Curi R. Modulation of lymphocyte proliferation by macrophages and macrophages loaded with arachidonic acid. Cell Biochem Biophys. 2005;23:373-381.

60. Declair $V$. The usefulness of topical application of essential fatty acids (EFA) to prevent pressure ulcers. Ostomy Wound Manag. 1997;43:48-52.

61. Pieper B, Caliri M. Nontraditional wound care: a review of the evidence for the use of sugar, papaya/papain, and fatty acids, J Wound Ostomy Continence Nurs. 2003;30:175-183.

62. Ruthig D, Meckling-Gill K. N-3 and n-6 fatty acids stimulate restitution by independent mechanisms in the IEC- 6 model of intestinal wound healing. J Nutr Biochem 2002;13:27-35.

63. Caffrey B, Jonsson HT J. Role of essential fatty acids in cutaneous wound healing in rats. Prog Lipid Res. 1981;20:641-647.

64. Burney D, Goodwin C, Caldwell M, Amoury R. Essential fatty acidy deficiency and impaired wound healing in an infant with gastroschisis. Am Surg. 1979;45:542.

65. Simpson D, Ross $R$. The neutrophilic leukocyte in wound repair a study with antineutrophil serum. J Clin Invest. 1972;51:2009-2023.

66. Wilgus TA. Immune cells in the healing skin wound: Influential players at each stage of repair. Pharmacol Res. 2008;58:112-116.

67. Dovi J, He L, DiPietro L. Accelerated wound closure in neutrophildepleted mice. J Leukoc Biol. 2003;73:448-455.

68. Pereira LM, Hatanaka E, Martins EF, Oliveira F, Liberti EA, Farsky SH, Curi $\mathrm{R}$, Pithon-Curi TC. Effect of oleic and linoleic acids on the inflammatory phase of wound healing in rats. Cell Biochem Funct. 2008;26:197-204.

69. Cardosoa CR, Oliveiraa LL, Vancima D, Barbana JO, Ferraza GB. Oleic acid modulation of the immune response in wound healing: A new approach for skin repair. Immunobiology. 2011;216:409-415.

70. Jouvenaz G, Nugteren D, Beerthuis R, Van Dorp D. A sensitive method for the determination of prostaglandins by gas chromatography with electron-capture detection. Biochim Biophys Acta. 1970;202:231-234.

71. Calder P. N-3 fatty acids, inflammation, and immunityrelevance to postsurgical and critically ill patients. Lipids. 2004;39:1147-1161.

72. Dirier A, Akmansu M, Bora H. The effect of vitamin E on acute skin reaction caused by radiotherapy. Clin Exp Dermatol. 2007;32:571-573.

73. Panin G, Strumia R, Ursini F. Topical a-tocopherol acetate in the bulk phase. Eight years of experience in skin treatment. Ann N Y Acad Sci. 2004:1031:443-447.

74. Khoosal D, Goldman R. Vitamin E for treating children's scar: does it help reduce scarring? Can Fam Physician. 2006;52:855-856.

75. Greenwald D, Scharzer L, Padawer J, Levenson S, Seifter E. Zone II flexor tendon repair: effects vitamin A, E and beta-carotene. J Surg Res. 1990;49:98-102.

76. Taren D L, Chvapil M, Weber CW. Increasing the breaking strength of wounds exposed to preoperative irradiation using vitamin $\mathrm{E}$ supplementation. Int J Vitam Nutr Res. 1987;57:133-137. 